Foster, R.M., Reynolds, T.P.S. and Ramage M.H. (2016) "Proposal for defining a tall, timber building”,

\title{
Proposal for defining a tall, timber building
}

\author{
Robert M. Foster \\ Research Associate, Centre for Natural Material Innovation, Department of Architecture, University of \\ Cambridge. Corresponding author email: rmf41@cam.ac.uk

\section{Thomas P.S. Reynolds} \\ Research Associate, Centre for Natural Material Innovation, Department of Architecture, University of \\ Cambridge, email: tpsr2@cam.ac.uk
}

\section{Michael H. Ramage}

Senior Lecturer in Architectural Engineering, Director Centre for Natural Material Innovation, Department of Architecture, University of Cambridge, email: mhr29@cam.ac.uk

\section{Introduction}

William Le Baron Jenney's 10-story Home Insurance Building in Chicago, completed in 1885, was the first iron-framed skyscraper (Gottmann 1966). Less than thirty years later, in 1913, the steel-framed Woolworth Building in New York was completed at a height of 60 stories (Gottmann 1966). After only 18 more years, in 1931, the steel framed Empire State Building reached a height of 102 stories (Ali \& Moon 2007). More recently, in 2008, a nine story residential building constructed from timber was completed at Murray Grove in London (Thompson 2009). This was the tallest 'timber' residential building in the world for only four years until the construction of the Forté building in Melbourne (Perkins + Will 2014). Three years later the Treet building in Bergen reached a height of 14 stories (Malo et al. 2016). While it is far from certain what heights tall buildings constructed using timber might ultimately reach, the historical precedent suggests that very significant increases in the height of such buildings may be possible in the coming years.
Regardless of structural material, Khan (1969) noted that there is a structural premium to be paid for increasing building height. Khan conceived this premium as the difference in cost between a design governed by the vertical load resisting system and a design governed by the lateral load resisting system. This premium is principally due to the relationship between building height and the forces that must be resisted by the lateral load resisting system. While the forces carried by the vertical load resisting system increase more or less linearly with height, the demand on the lateral load resisting system increases by the power of two. The greater wind velocities associated with increasing height above the earth's surface exacerbate this effect. As a result of both increasing lateral and vertical loads, for a given design stress, each additional story necessitates enlargement of the structure below; simultaneously adding cost and reducing usable floor area. Vertical transportation considerations may further decrease the marginal return of increasing height, as enhanced elevator provision increases cost and further decreases internal 
Foster, R.M., Reynolds, T.P.S. and Ramage M.H. (2016) "Proposal for defining a tall, timber building”,

area. In the words of Willis (1995), "At some point in the construction of every skyscraper, the law of diminishing returns sets in, and rents for additional stories do not cover costs". Willis (1995) characterizes the height at which the incremental return on investment decreases to zero, as the "economic height" of the building.

Moon et al. (2007) indicate that, notwithstanding variations in location and construction type, building heights in the range of 50-70 stories are likely to be most economic. However, the present heights of buildings using timber as a structural material are far below these heights. This indicates that there remains a significant deficit in our understanding and experience of the use of structural timber at heights that are likely to be of broad architectural and economic interest.

In order to encourage productive discussion and ensure that meaningful comparisons can be made between buildings using different structural systems and materials, it is useful to clarify what is meant by a 'tall, timber' building. The basis for such a clarification should be both the historic and commonly understood terminology and definitions, and also the facts of timber used as a structural material in multi-story buildings. As a result, the approach adopted in this paper has three parts:

1. Existing definitions and terminology for 'tall' buildings are explored.

2. A study is made of the structural systems and materials of existing buildings that use structural timber and have some claim to 'tallness'.
3. A proposal is made for the clarification and expansion of existing criteria for tall building terminology and definitions to accommodate the use of structural timber in tall buildings.

\section{Existing definitions and terminology}

\section{Tallness}

Tallness and height are not, in general, the same thing. Height is objective; it is a measurable property of a physical object. Tallness is subjective; it is a description of a physical object in which some form of contextual reference is implicit. While the more or less fixed height of a human being means that the tallness of a building is not entirely independent of its height, differences in context can lead to considerable variation in apparent 'tallness'. Precisely where height is measured 'from' and 'to' for the purposes of record keeping and comparison is important, and is discussed in greater detail below, but it is a fundamentally different consideration to that of what makes a building 'tall'.

A building may be considered tall with respect to one or more of a number of different considerations. One such consideration is the context provided by the historical use of a particular structural material or building structural system. In this sense a building that is taller than previous buildings of a particular material or type might be said to be "tall" with the implicit meaning of tall for a ... building. Tallness in this sense is of significance to the structural engineering community because the practice of structural design must draw on experience as well as theoretical understanding of structural behavior. The design of structures 
Foster, R.M., Reynolds, T.P.S. and Ramage M.H. (2016) "Proposal for defining a tall, timber building”,

that exceed the height of precedents using similar materials or systems thus places an additional burden upon the structural engineer.

Another consideration that has historically played a role in the technical, if not the colloquial, definition of building tallness, is that of fire. A tall building in this regard can thus be argued to be any building whose height is such that a fire cannot be fought from equipment based on the ground exterior to the building. The height beyond which firefighters would be required to fight a fire from within the building has thus constituted an historical "basic height limit" in North America (Calder et al. 2014) and elsewhere. The performance of structural timber in fire is the subject of ongoing research both at sub-element (Fragiacomo et al. 2013), element (Klippel et al. 2014) and whole building scales (Frangi et al. 2008). It seems reasonable to suggest that as understanding and experience of the fire design and protection of structural timber continues to improve, the perceived significance of this basic height limit as a contributor to perceptions of building tallness will diminish, as has been the case for structural steel and concrete.

The Council for Tall Buildings and Urban Habitats (CTBUH) identifies three further categories of qualities contributing to a definition of tallness (CTBUH 2015):

- height relative to context,

- proportion; and

- use of tall building technologies.

Height relative to context acknowledges that the built environment in which a building is sited has a significant influence on the perception of that building as tall or otherwise.
A 14 story residential building sited in a suburban neighborhood may be described locally as a tall building or a tower, whilst the same building situated in a high-rise cityscape might appear conspicuously less tall than surrounding buildings.

Proportion, rather than considering a relationship to the external context, can be thought of as considering a building in the context of its own geometry and massing. A 14 story building on a small footprint may appear slender, and hence tall, in a way that a building of the same height covering an entire city block may not. Building proportion may be considered in an approximate fashion in terms of slenderness or aspect ratio; this being the ratio of the structural height to the smaller lateral structural dimension of the structure. An indicative characterization of tallness with respect to relative height and slenderness is shown in Figure 1.

Tall building technologies refers to considerations such as advanced vertical transportation, enhanced lateral force resisting and damping systems that are particular to the design of tall buildings. The need for enhanced lateral force resisting and damping systems is closely related to the slenderness of a building. This aligns with Khan's (1969) definition of "high-rise construction" from the point of view of the structural engineer as being predicated upon the relative significance of:

- lateral forces due to wind and seismic actions;

- actual lateral sway;

- perceived lateral sway;

- differential vertical movements due to thermal effects or axial shortening 
Foster, R.M., Reynolds, T.P.S. and Ramage M.H. (2016) "Proposal for defining a tall, timber building", J. Struct. Eng., http://dx.doi.org/10.1061/(ASCE)ST.1943-541X.0001615

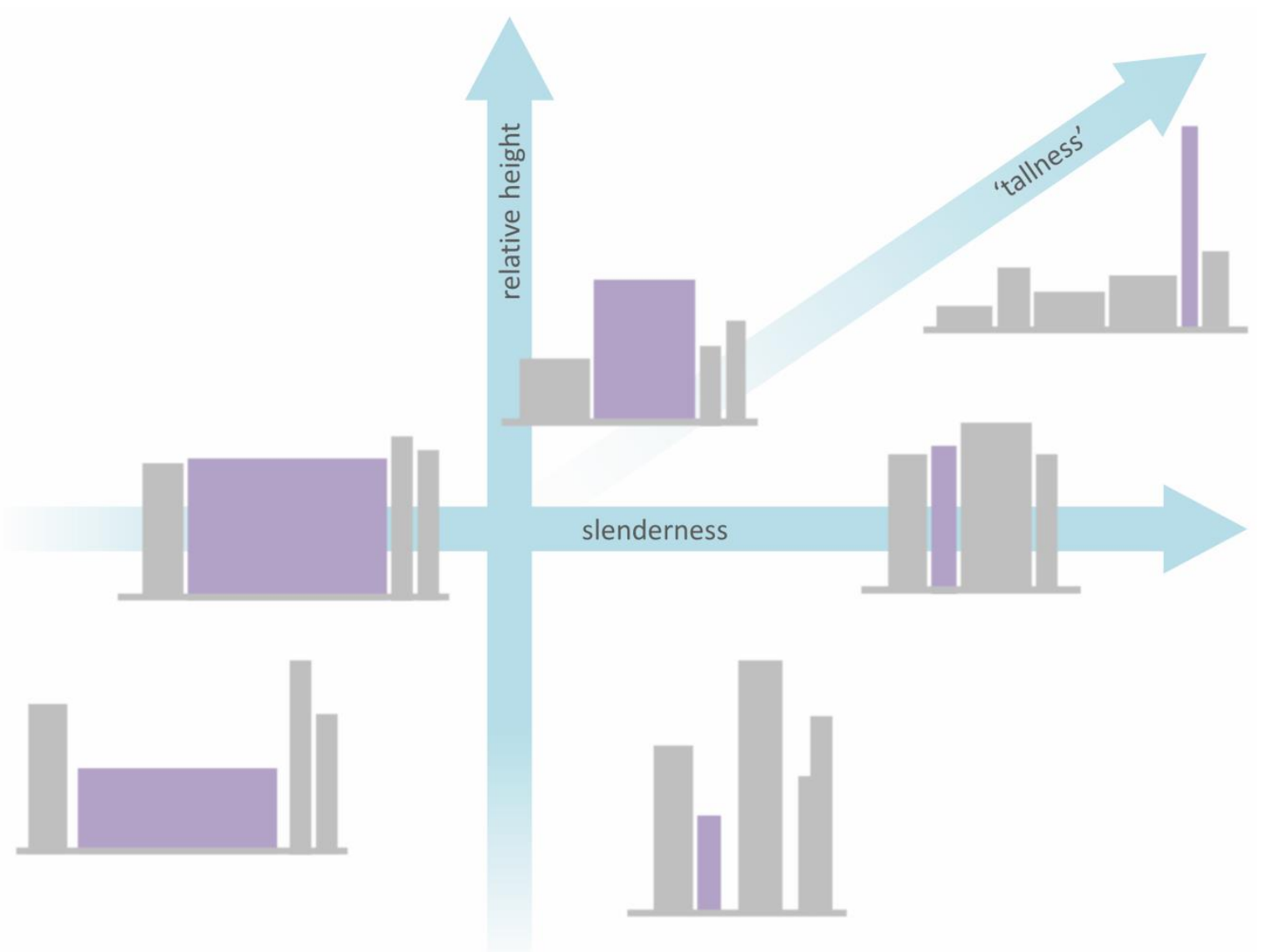

Figure I. Appearance of tallness

Slenderness ratios of less than six generally mean that the design of lateral load resisting structural systems will not present a particular challenge; while slenderness ratio of eight or greater place high demands on the lateral load resisting structural system and the dynamic behavior of the building due to wind or seismic action is likely to govern the structural design (fib 2014). Slenderness can also affect code provisions for robust structural design. For example, Chapter 16 of the New York City Building Code (City of New York 2014) provides additional requirements with respect to key element design and structural peer review for buildings with slenderness ratios equal to or greater than seven.

A definition of tallness with respect to tall building technologies is thus rather interesting with respect to the consideration of 'new' structural systems and materials - such as engineered timber. It might be expected that the relatively low stiffness and mass of timber will lead to wind or seismic actions governing 
Foster, R.M., Reynolds, T.P.S. and Ramage M.H. (2016) "Proposal for defining a tall, timber building”,

design at considerably lower slenderness ratios. As a result something analogous to 'tall' building structural systems would be required by buildings using structural timber at lesser building heights than they might become necessary in steel or concrete buildings. The timber bracing across multiple stories in the 14-story Treet building, at a height for which story-high bracing would be conventional in steel, might be taken as an example of this. It might then be suggested that buildings using structural timber might be considered 'tall' at lesser heights than similarly sited and proportioned buildings using steel or concrete. However, Malo et al. (2016) argue that the comparable specific strength and stiffness of steel and glue-laminated timber mean that the stiffness and mass of a braced glue-laminated timber building will not be dissimilar to that of a braced steel building. Although not detailed by Malo et al. (2016), the authors estimate that the bulk density of the Treet building (calculated as dead load divided by gross building volume) to be approximately 140 $\mathrm{kg} / \mathrm{m}^{3}$. The authors' experience in practice, and analysis in the literature (Cho et al. 2004, Yang et al. 2004, Huang et al. 2007), suggest that approximate bulk densities for typical steel and concrete buildings may be of the order of $160 \mathrm{~kg} / \mathrm{m}^{3}$ and $300 \mathrm{~kg} / \mathrm{m}^{3}$ respectively. Malo et al. (2016) also estimated the fundamental frequency of the Treet building structure at slightly greater than $1 \mathrm{~Hz}$ following a simplified approach originally intended for steel. A preliminary invivo output-only assessment of wind-induced vibration of the Treet building by random-decrement technique (Reynolds et al., unpublished data, 2015) suggests the Malo et al. (2016) estimate to be approximately correct. The Treet example thus provides a preliminary indication that a braced glue-laminated timber structure building may be designed to have similar mass and exhibit similar dynamic behavior to a braced steel frame building. This result suggests that it may be not be necessary to establish different criteria on the basis for tallness for buildings using structural timber on the basis of material properties alone.

\section{Height}

Unlike tallness, building height is relatively straightforward to define, provided that there is common understanding of where is being measured from and to. Since building forms vary, even within broadly similar typologies, detailed definitions of the bottom and top of a building are inevitably somewhat arbitrary. However, a number of broadly agreed measures are currently in use for the reporting and cataloguing of building height.

The CTBUH recognizes three categories of tall building height:

- height to architectural top;

- highest occupied floor; and

- height to tip.

These heights are defined as being measured from the finished floor level of the lowest, open-air pedestrian entrance leading to the main vertical transport that serve the building proper. The height to tip measurement can include projections such as antennae that are not integral and may not be permanent features of the building. The height to architectural top or gross height provides the basis for the widely cited CTBUH list of World's Tallest Buildings and is measured to the permanent top of the building, including features such as spires but excluding antennae. Buildings are 
Foster, R.M., Reynolds, T.P.S. and Ramage M.H. (2016) "Proposal for defining a tall, timber building”,

designated as super- and megatall by the CTBUH (2015) if the gross height exceeds $300 \mathrm{~m}$ and $600 \mathrm{~m}$ respectively. The difference between the height to architectural top and the highest occupied floor is often referred to as vanity height (CTBUH 2013) and, where significant, can obscure meaningful comparison between buildings. The measurement to the highest occupied floor or net height is thus of greatest practical interest for the comparison of tall buildings as devices for the vertical stacking of people. The height to occupied floor, or simply the number of occupied floors, is thus likely to be the measure of greatest interest for meaningful comparison of height between tall buildings in general. Although a net height of approximately 14 stories or $50 \mathrm{~m}$ is suggested by the CTBUH (2015) criteria as a starting point for consideration of a building as tall, this does not preclude a shorter building from being considered as tall on the basis of the use of tall building technologies.

\section{Structural system}

Khan (1969) proposed a schematic relationship between tall building structural systems and the characteristic height ranges of buildings for which each system represents an efficient structural solution. The original structural systems charts were subsequently updated and expanded upon by Khan and various later investigators (Iyengar 2000). Numerous investigators have attempted to provide further systems for classifying tall building structural systems (Falconer 1981, Ali \& Moon 2007, Gunel \& Ilgin 2007). Although the structural system categories themselves may be more or less applicable to structural materials in general, the indicative heights have only been established buildings constructed using steel and / or concrete. Structural system typologies are variously associated with a number of considerations including: different relationships between vertical and lateral loads; the resulting vertical and lateral movements of the structure; and the associated variation in the economic use of bending and axial structural member actions. Differences in the density, strength and stiffness of structural materials and connection types will therefore vary the building heights at which a given structural system is economic, as will differences in material and construction costs. Indicative heights for economic tall building structural systems using timber have yet to be established.

\section{Structural material}

Timber was a key material in the construction of churches and spires that what would have been regarded as tall structures until the early 20th Century (Constantinescu 2008). The tallest timber structures ever constructed are transmission masts, with the now dismantled $190 \mathrm{~m}$ Ismaning radio tower in Germany the tallest on record (Langenbach 2008).

Although tall, structures such as spires and transmission masts are not readily comparable to the occupied multi-story buildings that are of principal interest in the contemporary built environment. Indeed, such structures would be excluded from consideration as tall buildings, in this sense, by the CTBUH (2015) criteria on the basis that less than $50 \%$ of the building height can be considered as "occupied by usable floor area". The Yingxian Pagoda in China is reported to have a height between $62.12 \mathrm{~m}$ (Lam et al. 2008) and $67.13 \mathrm{~m}$ (Langenbach 2008) including a spire of approximately $10 \mathrm{~m}$. While this pagoda has multiple stories, the dense and intricate system 
Foster, R.M., Reynolds, T.P.S. and Ramage M.H. (2016) "Proposal for defining a tall, timber building”,

of stacked joints between levels accounts for so much of the pagoda's height that there are only five floors. This means that, with reference to contemporary floor-to-floor heights, the building is effectively not occupied by usable floor area for over $50 \%$ of its height.

All present supertall and megatall buildings, and indeed the very vast majority of buildings with any generally recognized claim to tallness, are constructed using steel, concrete or a combination of the two as the principal structural materials. While no large or tall building is constructed entirely of one material - structural concrete contains steel reinforcement and the structural flooring in a steel framed building is typically some form of concrete deck (Gunel \& Ilgin 2007) - it can be informative to consider broad classification on the basis of principal structural building material use. Tall buildings are classified by the CTBUH (2015) into four typologies according to the material(s) adopted for the construction of the "main" vertical and lateral structural elements. These categories are presently:

- steel;

- concrete;

- composite; and

- mixed-structure.

A steel or concrete building is a building in which the main structural elements are constructed from steel or concrete. A composite building is a building which uses steel and concrete elements to form the main vertical and / or lateral load resisting systems. This category would include the common structural form of a steel framed building with a concrete core. A mixed-structure building is a building which uses distinct steel and concrete structural systems above or below each other. A steel / concrete building uses a steel structural over a concrete structural system; and a concrete / steel building uses a concrete structural system over a steel structural system. In this sense the upper structural system of a mixed-structure building can be thought of as a separate building structure founded on the lower.

A building with a steel frame but with a flooring system of concrete planks or slabs supported by steel beams is considered by the CTBUH (2015) as a steel building. As such the floor system is not considered to form part of the "main" structural system, even though considerations such as diaphragm action or mass contributed by the flooring system may form an important part of the design of the "main" structure. This definition is compatible with the distinction sometimes drawn in terms of design responsibility in structural engineering practice between the 'primary' structure, for which the structural engineer is responsible, and 'secondary' structure, which may be a proprietary system or contractordesigned element.

The existing definitions and terminology may be readily expanded to accommodate the use of timber, or other structural materials such as bamboo or fiber reinforced polymer composites, in tall building construction. In so doing, it is useful to rationalize the existing definitions and categories building structures as;

- $\quad$ single material;

- composite; and

- mixed. 
Foster, R.M., Reynolds, T.P.S. and Ramage M.H. (2016) "Proposal for defining a tall, timber building", J. Struct. Eng., http://dx.doi.org/10.1061/(ASCE)ST.1943-541X.0001615
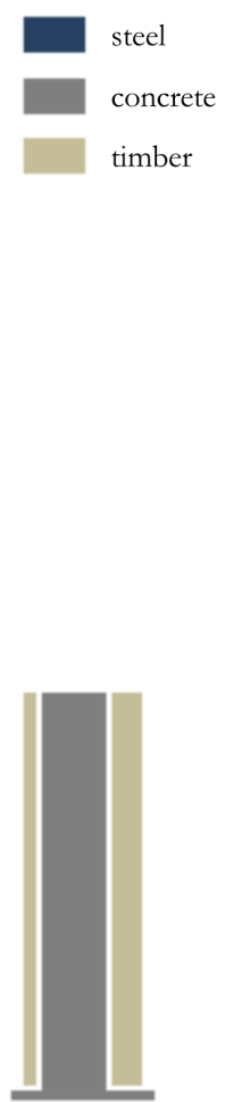

composite building: concrete-timber

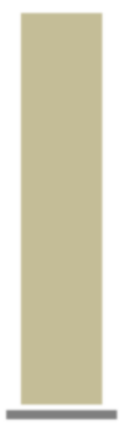

single material building: timber

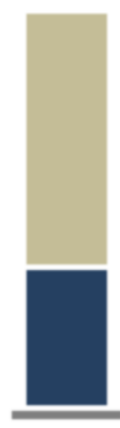

mixed building: timber/steel

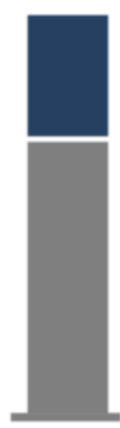

mixed building: steel / concrete

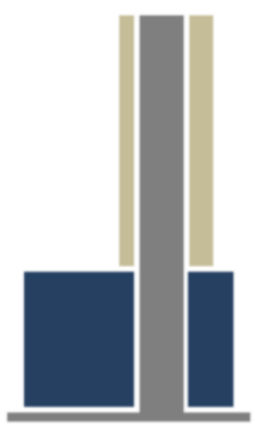

composite building: timber-steel

mixed composite building: concrete-timber/steel-concrete

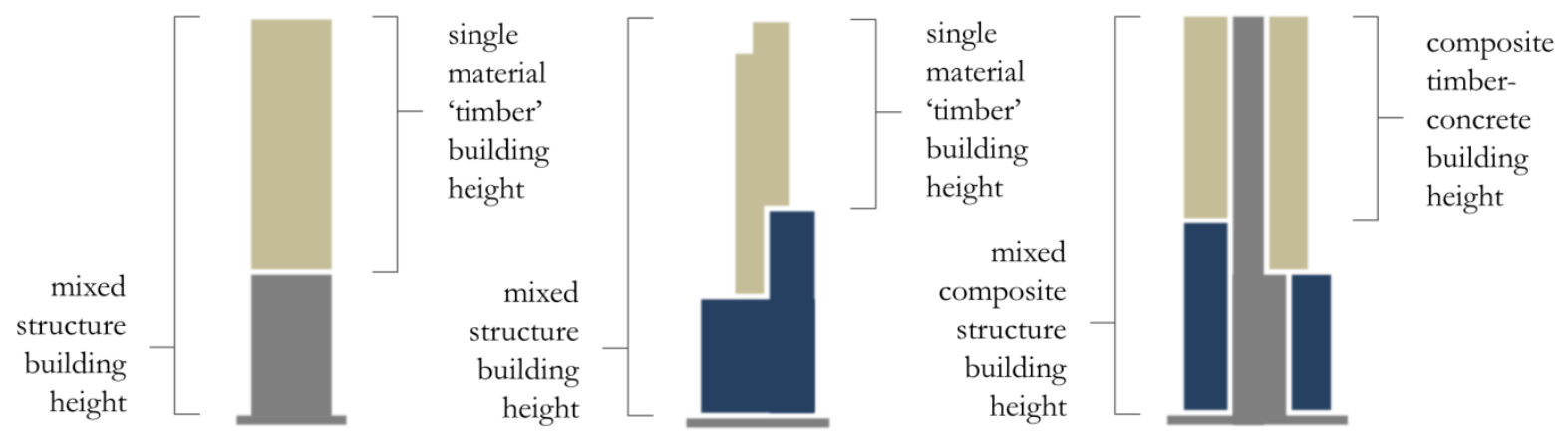

Figure 2. Examples of building type by structural material

A single material tall building - a tall steel building, a tall concrete building, a tall timber building, etc. - is thus a building in which the main structural elements are constructed principally from a single material. This allows a steel or concrete building to be defined as before, but as a subset of the single material category, rather than privileging these over 
Foster, R.M., Reynolds, T.P.S. and Ramage M.H. (2016) "Proposal for defining a tall, timber building”,

other potential structural materials. The materiality of any secondary flooring structure, such as concrete decking, would not affect the definition of the 'primary' structural material classification (Gunel \& Ilgin 2007). This is compatible with the current guidance for the definition of, for example, a tall steel building with concrete floor slab supported on steel beams (CTBUH 2015).

The definitions of composite and mixed buildings would remain largely unaffected except in so far as reference to steel and concrete might be replaced with reference to materials in general. It is suggested that for clarity, a composite building is designated by the constituent structural materials, hyphenated, in order of prevalence by mass in the building structure. Thus a composite building with a large concrete core and a smaller quantity of timber framing would be designated as a concrete-timber composite building, while a mass timber building with limited concrete linking beams would be designated a timber-concrete composite building.

It is useful to introduce a further clarification to the idea of a mixed-material building such that the upper structural section of a mixedmaterial building can also be described as a single-material building measured from the height of the lower structure from which it takes support. Similarly, where a building is a mixed composite building - for example a building with a full height concrete core, a lower section of steel framing and an upper section of timber framing - the upper section could be considered a concrete-timber composite building measured from the height of the concrete-steel composite structure. This is akin to considering the lower structural section as an elevated foundation or plinth. This is particularly relevant for the description of buildings using materials such as timber where, in order to prevent the uptake of water through the end grain (APA 2007), vertical timber elements may be required to begin above external ground level (IStructE \& TRADA 2007). Concrete may also be more suitable for the transfer structures required to accommodate a more open grid for retail spaces at street level. For these reasons, predominantly timber buildings often incorporate a single material concrete structure up to first floor level. A building constructed in concrete to first floor, with 20 stories of timber above could be accurately described as a 21 story mixed timber / concrete building. However, it would be useful in terms of chronicling the development of building technology and design, to also consider such a building as a twenty story timber building indeed, at the time of writing, it might be considered the world's tallest 'timber' building. Examples of the proposed classifications with respect to various notional building arrangements are shown in Figure 2.

\section{Study}

A number of buildings using structural timber - mostly constructed in the past decade - have been described informally as 'tall timber' buildings. A trend towards further use of engineered timber in taller building structures in both non-seismic and seismic zones has been identified (Pei et al. 2016). The structural systems and materials used in many of these buildings are surveyed here (Table 1). Buildings that are known to be under construction at the time of writing are considered to be realized designs for the purposes of this study. Also included are a 
Foster, R.M., Reynolds, T.P.S. and Ramage M.H. (2016) "Proposal for defining a tall, timber building”,

number of published concept designs for unrealized tall buildings using structural timber. While the majority of buildings constructed to date are found in Europe and Australia, the authors are aware of rapid development in North America with the T3 building in Minneapolis under construction at the time of writing and plans for an 18 story hall of residence for UBC in Vancouver. Also understood to be in development are plans for the 10 story 475 West $18^{\text {th }}$ Street building in New York and the 12 story Framework building in Portland, partly in response to the Tall Wood Building Prize offered by the US Department of Agriculture with the Softwood Lumber Board and the Binational Softwood Lumber Council.

This study has been carried out with a view to understanding the structural systems adopted for the design of 'tall, timber' buildings and the material composition of those structural systems. This research provides a basis for evaluating the suitability of existing terminology and definitions for tall buildings, in light of the characteristics of actual buildings using structural timber.

\section{Structural materials and structural systems}

The building height, measured in stories, for all of the buildings considered in this study are shown in Figure 3, along with the approximate date of actual or expected construction. The building structural material is also indicated and characterized according to the criteria established in the previous section. Aside from Butler Square, which was built a century previously, all of the buildings considered are more or less contemporaneous; all having been constructed within the last ten years. Of the eight non-composite buildings, five are mixedstructure buildings, having a concrete structure at the primary access level, whilst the others are timber at all levels. At 18 stories the proposed timber-concrete composite structure UBC Brock Building is rather higher in story terms than any of the constructed buildings considered in this study but significantly less high than a number of the concept buildings considered.

A number of structural systems were found to have been adopted for the vertical and lateral load resisting systems of the buildings studied. These systems are summarized in Table 1. Also included in Table $\mathbf{1}$ is the presence of concrete screed (where known) that is, or is likely to have been, considered as a permanent action or ballast for the purposes of design against tension at the base due to uplift or overturning.

\section{Discussion of 'hard' cases}

As with any attempt to systematically categories real things, this study identified a number of buildings which presented challenges to classification, particularly with respect to structural material. Rather than looking to the extrema, the authors have adopted the maxim that, "... hard cases make bad law" (Holmes 1904). As such, the categorization has been carried out with reference to the basic principles discussed above, rather than introducing a more complex system of classification. The authors' thinking with respect to treatment of some of these 'hard' cases is set out below. 
Foster, R.M., Reynolds, T.P.S. and Ramage M.H. (2016) "Proposal for defining a tall, timber building",

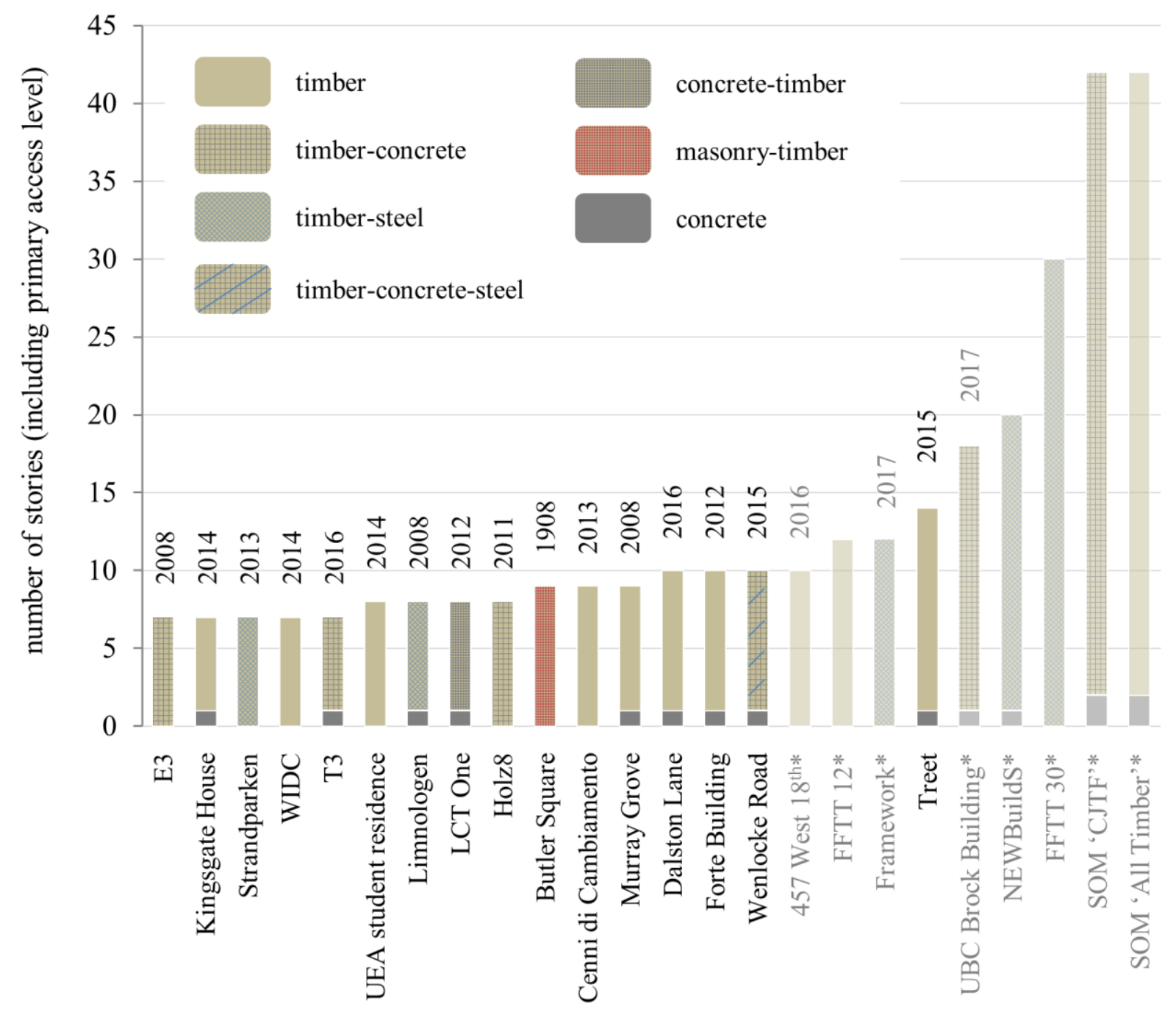

Figure 3. Building structural material by story (unrealized buildings indicated by asterisk *)

\section{Treet}

At 14 stories tall the Treet building is the only completed building identified that might be on the threshold for being considered a tall building, purely in terms of height, with reference to existing guidance (CTBUH 2015). Although having a slenderness ratio of approximately two, the expressed building structural system is that of partially connected braced glued laminated timber (glulam) frames. The structural system acts as a "cabinet rack filled with drawers" (Malo et al. 2016); the shelves of the "cabinet rack" being transfer stories composed of glulam trusses with a $200 \mathrm{~mm}$ reinforced concrete topping slab and the "drawers" being prefabricated timber modules. The braced glulam frames acts as the primary vertical and lateral load resisting system with the stacked modules 
Foster, R.M., Reynolds, T.P.S. and Ramage M.H. (2016) "Proposal for defining a tall, timber building”,

taking vertical support only at the transfer stories and bearing onto the glulam frame via the reinforced concrete topping slab. The module walls align with the trusses below, meaning that the slab itself is not designed to act as a transfer structure. The concrete is considered in the design to provide only mass and diaphragmatic stiffness - as might be expected in a steel building with concrete floor system supported on steel beams. For this reason, the view taken by the authors is that this slab is not acting as a primary load path, other than in the sense that it interrupts contact between the base of the module and the glulam beam. The building has thus been classified here as a mixed timber / concrete structure or a single material timber building above the concrete $1^{\text {st }}$ floor podium. The ballast that may be deemed a beneficial permanent action against uplift provided by the $200 \mathrm{~mm}$ concrete slab at five story intervals is also comparable, in terms of mass, to a $40 \mathrm{~mm}$ concrete screed at each story level. Despite the additional mass provided by the concrete topping slabs, uplift forces are developed under some lateral load cases and the glulam structure is designed to provide the associated tension load paths to the concrete substructure and tension piles (Malo et al. 2016).

\section{Limnologen, Strandparken and Framework}

The Limnologen and Strandparken buildings do not incorporate significant concrete in either the primary structure or as a flooring material, other than the concrete $1^{\text {st }}$ story of the Limnologen building. The lightness of the resulting structures has led in both cases to the use of steel rods running the full height of the building through the Cross-Laminated Timber (CLT) shear walls; acting as continuous ties against uplift. These ties provide the primary tension force path of the lateral load resisting system. The Framework building design indicates the use of steel ties to externally posttension the CLT shear walls, creating a rocking-wall system to accommodate seismic loads. The lateral load resisting system in each case is thus a composite timber-steel system making use of the complementary properties of the two materials. Limnologen has thus been classified here as a mixed structure timbersteel composite / concrete building; and Strandparken and Framework as timber-steel composite buildings. Notwithstanding this classification, the authors recognize that under alternative methods of classification, say in terms of overall material composition, the Strandparken building in particular might be considered amongst the most 'timber' of the buildings considered.

\section{Consideration of connections}

All of the buildings considered in this study use steel or steel and concrete connections to facilitate the local transfer of forces between timber structural elements. While methods for fabricating all-timber connections at a building scale are well established in the carpentry traditions of countries such as Japan (Nakaharo 1990), these connections are not generally used in larger modern buildings. A notable exception to this is the timber vertical, but not lateral, load resisting system of the six story Tamedia building (Perkins + Will 2014).

To classify all building designs that use steel or concrete to form connections between timber elements as composite would thus render the category of 'timber' building, in a modern design context beyond the domestic scale, more or less empty. For this reason, the 
Foster, R.M., Reynolds, T.P.S. and Ramage M.H. (2016) "Proposal for defining a tall, timber building”,

materiality of connections between timber elements is not considered in the classification scheme presented. This is comparable with the use of steel connections in a tall building with a precast concrete frame or with reinforcing bars crossing a cold-joint in a tall building with a monolithic concrete frame, both of which would in most cases be regarded as concrete rather than composite tall buildings.

There has been much ongoing research into the behavior of connection systems for crosslaminated timber (Gagnon \& Pirvu 2011, Tomasi et al. 2015, Kramer et al. 2015) and glue-laminated timber (Reynolds et al. 2014, Zarnani et al. 2014, Malo et al. 2016). A range of connection types are evident in the buildings considered. CLT solutions generally adopted screwed or nailed steel brackets as at Murray Grove (Thompson 2014), Forté (Perkins + Will 2014) and Dalston Lane (Pearson 2016), or combinations of long selftapping screws with plate-in-groove and dowel systems at Cenni di Cambiamento (Perkins + Will 2014) to carry tensile and / or shear forces across a joint. Compressive forces in most cases were carried by the timber in bearing. Where compressive stresses exceeded the design stress of the unreinforced timber perpendicular-to-grain, a number of strategies were adopted including: local bearing enhancement with screws at Murray Grove (Thompson 2009) and discrete grout pockets at Dalston Lane (Pearson 2016). The designers of the braced frame Treet building adopted dowelled steel plate connections of a size and type previously used for timber bridge construction (Malo et al. 2016) with both compressive and tensile forces transferred across the joint by the steel connection.
While it is beyond the scope of this forum paper to provide a full discussion of the role of connections in the performance of timber structures, the authors recognize that connection stiffness and ductility is of fundamental importance in design and that the local performance of connections may govern the behavior of the structure as a whole, particularly under seismic loading. The purpose here is to highlight that a variety of methods are used to form connections in timber structures and that that it would be difficult to incorporate their detail into a simple characterization of building structural material.

\section{The future of tall timber}

There is insufficient evidence at present to make a judgement as to the likely economic heights of different structural systems using timber. However, this study has yielded some preliminary indications as to the nature of efficient and / or economic use of timber.

The CLT walled systems that make possible an efficient 'platform' construction approach have not yet been shown to be economic for buildings above 8-10 stories. Considerations such as cross-grain crushing of floor panels are thought to limit the capacity of the vertical load resisting system in such cases; and limited coupling of timber core and shear walls are thought to limit the capacity of the lateral load resisting system. While technological improvements are likely to increase the structural feasibility of walled systems at greater height, the choice of a braced frame system as the most economical for the 14 story Treet building (BOB, personal communication, $22^{\text {nd }}$ October 2015) provides an indication that 
Foster, R.M., Reynolds, T.P.S. and Ramage M.H. (2016) "Proposal for defining a tall, timber building”,

the present economic height of platform systems may not greatly exceed 10 stories.

A number of advantages of composite structural elements using concrete and timber have been shown previously (Yeoh et al. 2011, Zhang et al. 2015). The unrealized concept designs that exceed the height of the tallest timber buildings already constructed indicate a further trend toward composite structures. It is significant that SOM (2013) concluded that although a nominally "All Timber" 42 story tower design was structurally feasible, there were significant diseconomies compared to a composite "Concrete Jointed Timber Frame (CJTF)" equivalent. The CJTF design has thus been the option taken forward by SOM for further conceptual design development. This might be taken as indicating that the economic height of the timber option is lower than that of the composite option in this hypothetical case. Baker et al. (2014) further suggest that the composite CJTF system may be competitive with comparable steel and reinforced concrete solutions with a saving of $60-75 \%$ in carbon emissions.

The particular demands of tall building design are such that the economy of the structure may govern the economy of the whole building to a greater extent than in low- and mid-rise building design. This means that the appropriate choice of structural systems and materials in such cases may be critical to the viability of a scheme. It is to be expected that a composite structure that takes advantage of the heterogeneous properties of the different structural materials available for tall building design might provide the greatest economic height in a given situation - provided that construction is not unduly complicated by the mixing of materials. For this reason, it appears likely that the immediate future of structural timber in tall building design is as a part of a timber-steel or timber-concrete composite structure. However, improvement in design and ongoing research into the development of advanced engineered timber, bamboo and other plant based material products raises the prospect of tall single material timber buildings.

The development of distinct lateral load resisting systems in large commercial buildings at the end of the nineteenth century, which made possible the rapid progression in tall building height of the early twentieth century, has been identified as having been strongly influenced by the transfer of understanding from bridge engineering into the design of buildings (Leslie 2010). Indeed, it has been said that the 1889 Eiffel Tower was "not a tower but a huge bridge that Eiffel had made to stand up" (Gottmann 1966). It is thus interesting to note that the structural system and connections of the Treet building, identified here as the current tallest timber building, have been directly influenced by its designers' experience of timber bridge construction in Norway (Malo et al. 2016). The lessons that may be learned from the engineering of timber bridges may thus be a further fruitful avenue of future research in relation to the design of tall, timber buildings.

\section{Conclusions and proposals}

The discussion of building 'tallness' has indicated that although there are reasons to suggest that a timber building might be considered tall at a lesser height or slenderness than a steel or concrete building, these reasons are primarily a result of the relatively early stage of development of engineered timber as a 
Foster, R.M., Reynolds, T.P.S. and Ramage M.H. (2016) "Proposal for defining a tall, timber building”,

structural material for use in taller buildings.

There is enormous potential for the

development of structural systems for

engineered timber that will permit timber and

timber composite buildings to reach very much greater heights than at present. The

comparable specific strength and stiffness of

engineered timber and steel, the performance

of the Treet building, and the ambitious

concept designs being put forward by leading

architects and structural engineers worldwide,

provide a preliminary indication of this

potential. While it may be tempting in the

short term to 'lower the bar' for tall with

respect to timber, the authors contend that to

do so would be to underestimate the potential

of the material and of structural engineering

itself.

This study has also shown that, with limited modification, the existing terminology for tall buildings in relation to structural material may be applied in a consistent manner to buildings that use timber as a structural material.

Although the buildings surveyed in this study include some 'hard' cases, a classification based on the materiality of the primary structural load paths provides a generally consistent basis for understanding and comparison. This system has the advantage of being readily applied to buildings using new structural materials; and of being aligned with the existing terminology for steel and concrete buildings, expressed in the CTBUH (2015), 'Criteria for the Defining and Measuring of Tall Buildings'.

On the basis of the preceding discussion, the following criteria are proposed as a potential basis for the extension of the existing guidance to the description and classification of tall buildings using structural timber:
- A single material tall building is defined as one where the main vertical and lateral structural elements and floor systems are constructed from a single material. As such, a steel, concrete or timber tall building is defined as one where the main vertical and lateral structural elements and floor systems are constructed from steel, concrete or timber.

- A composite building utilizes a combination of steel, concrete and/or timber acting compositely in the main structural elements, thus including an otherwise steel or timber building with a concrete core. Materials may be listed in order of prevalence by mass in the building structure: for example, a timber-concrete composite tall building indicates that timber represents a greater proportion of the structure by mass. Note that a flooring system of concrete planks or slab supported on timber beams is not considered in assessing the relative proportions of material.

- A mixed-structure tall building is any building that uses distinct steel, concrete or timber systems above or below each other. There are three main types of mixed structural systems: a steel / concrete or timber / concrete tall building indicates a steel or timber structural system located above a concrete structural system, with the opposite true of a concrete / steel building

Additionally: 
Foster, R.M., Reynolds, T.P.S. and Ramage M.H. (2016) "Proposal for defining a tall, timber building”, J. Struct. Eng., http://dx.doi.org/10.1061/(ASCE)ST.1943-541X.0001615

- If a tall building is of steel or timber construction with a floor system of concrete planks or slab supported on steel or timber beams, it is considered a steel or timber building.

- If a tall building has columns or walls of one material and a floor system supported on beams of a different material, it is considered a composite tall building

- If a tall building is of timber construction with local connections between timber elements formed using steel or another material, it is

considered a timber building.

It is further suggested that in a similar fashion to the CTBUH (2015) definition of building use, which considers a mixed-use building to be a building in which more than one function occupies a significant proportion of a building's total space, a mixed-structure might be defined as one in which more than one single-material structure occupies a significant proportion of a building's height. The corollary of this definition, which is particularly relevant to the meaningful comparison of buildings using structural timber, is that where a single-material structure makes up more than approximately $85 \%$ of the building's height it could be classified as a single material building.

\section{Acknowledgements}

The authors' research is supported by EPSRC Grant EP/M01679X/1 and by a Leverhulme Trust Programme Grant. The authors would like to acknowledge the CTBUH Tall Timber Working Group for highlighting the need for clarification on this topic.

\section{References}

Ali, M. M. \& Moon, K. S. (2007) 'Structural Developments in Tall Buildings: Current trends and Future Prospects’, Architectural Science Review, Vol. 50, No. 3, pp. 205-223

APA (2007) Technical note: Glulam connection details, Form No. EWS T300H, APA, Tacoma

Baker, W.F., Horos, D.R., Johnson, B.M. and Schultz, J.A. (2014) 'Timber Tower Research: Concrete Jointed Timber Frame’, Structures Congress 2014, pp. 1255-1266, 10.1061/9780784413357.113

Calder, K., Senez, P., McPhee, R. (2014) 'The risk basis for height and area limits in North American building codes', World Conference on Timber Engineering (WCTE) 2014, August 10-14, Quebec City

Cho, H.W., Roh, S.G., Byun, Y.M. and Yom, K.S (2004) 'Structural quantity analysis of tall buildings', CTBUH Conference: tall buildings in historical cities - culture \& technology for sustainable cities, October 10-13, Seoul, South Korea

City of New York (2014) New York City Building Code, New York 
Foster, R.M., Reynolds, T.P.S. and Ramage M.H. (2016) "Proposal for defining a tall, timber building", J. Struct. Eng., http://dx.doi.org/10.1061/(ASCE)ST.1943-541X.0001615

Constantinescu, B. (2008) 'Romanian Architectural Wooden Cultural Heritage - The Present Status A Survey', In Proceedings of the International Conference held by cost actions IE (Vol. 601, pp. 265-270).

CTBUH (2013) 'Vanity Height: the Empty Space in Today's Tallest', CTBUH Journal, Issue 3, pp. 4243

CTBUH (2015) Criteria for the Defining and Measuring of Tall Buildings, Council on Tall Buildings and Urban Habitats,

[http://www.ctbuh.org/LinkClick.aspx ?fileticket=zvoB1S4nMug\%3d\&tabid=446\&language=en -US, accessed $5^{\text {th }}$ November 2015]

Falconer, D. W. (1981) 'Classification of Tall Building Systems, M.S. Thesis, May 1981', Fritz Laboratory Reports Paper 2224, Lehigh University, US

Frangi, A., Bochiccio, G., Ceccotti, A. and Lauriola, M.P. (2008) 'Natural full-scale fire test on a 3 storey X-Lam timber building', Proceedings of the 10th World Conference on Timber Engineering, S. Aratake [Ed.], Miyazaki, Japan

Fragiacomo, M., Menis, A., Clemente, I., Bochiccio, G. and Ceccotti, A. (2013) 'Fire resistance of cross-laminated timber panels loaded out of plane', ASCE Journal of Structural Engineering, Volume 139, Issue 2, 10.1061/(ASCE)ST.1943-541X.0000787

Green, M. and Karsh, E. (2012) The Case for Tall Wood Buildings, CC-BY-NC-SA: Vancouver

fib Task Group 1.4 (2014) Tall Buildings: Structural Design of Concrete Buildings up to 300m Tall, MPA The Concrete Centre and fédération internationale du béton (fib), London

Gagnon, S. and Pirvu, C. (2011) CLT handbook, cross-laminated timber, special publication SP-528E, FP Innovations, Québec.

Gottmann, J. (1966) 'Why the skyscraper?', Geographical Review, Vol. 56, No. 2, pp. 190-212

Gunel, M. H. \& Ilgin, H. E. (2007) 'A Proposal for the Classification of Structural Systems of Tall Buildings', Building and Environment, Vol. 42, pp. 2667-2675

Holmes, O.W. (1904) Northern Securities Co. v. United States, U.S. Supreme Court 193 U.S. 197, p. 400

Huang, S., Li, Q.S. and Xu, S. (2007) 'Numerical evaluation of wind effects on a tall steel building by CFD’, Journal of Constructional Steel Research, Vol. 63, No. 5, pp.612-627

IStructE \& TRADA (2007) Manual for the Design of Timber Building Structures to Eurocode 5, The Institution of Structural Engineers, London 
Foster, R.M., Reynolds, T.P.S. and Ramage M.H. (2016) "Proposal for defining a tall, timber building”, J. Struct. Eng., http://dx.doi.org/10.1061/(ASCE)ST.1943-541X.0001615

Iyengar, H. (2000) 'Reflections on the Hancock Concept', CTBUH Review, Vol. 1, No. 1, pp. 44-52

Khan, F. R. (1969) 'Recent Structural Systems in Steel for High-Rise Buildings', The British Constructional Steelwork Association, Proceedings of the Conference on Steel in Architecture, pp. 55-66

Klippel, M., Frangi, A and Hugi, E. (2014) 'Experimental analysis of the fire behavior of fingerjointed timber members', ASCE Journal of Structural Engineering, Vol. 140, No. 3, 10.1061/(ASCE)ST.1943-541X.0000851

Kramer, A., Barbosa, A.R. and Sinha, A. (2015) 'Performance of Steel Energy Dissipators Connected to Cross-Laminated Timber Wall Panels Subjected to Tension and Cyclic Loading', ASCE Journal of Structural Engineering, Vol. 42, Special Issue: Seismic resistant timber structures, 10.1061/(ASCE)ST.1943-541X.0001410, E4015013

Langenbach, R. (2008) 'Building Tall with Timber: A Paean to Wood Construction', Structural Engineering International, Vol. 18, No. 2, pp. 130-132.

Leslie, T. (2010) 'Built Like Bridges: Iron, Steel, and Rivets in the Nineteenth-century Skyscraper', Journal of the Society of Architectural Historians, Vol. 69, pp. 234-261

Malo, K.A., Abrahamsen, R.B. and Bjertnaes, M.A. (2016) 'Some structural design issues of the 14storey timber framed building "Treet” in Norway', European Journal of Wood and Wood Products, pp. 1-18, DOI: 10.1007/s00107-016-1022-5

Moon, K-S., Connor, J. J. and Fernandez, J.E. (2007) 'Diagrid Structural Systems for Tall Buildings: Characteristics and Methodology for Preliminary Design', The Structural Design of Tall and Special Buildings, Vol. 16, pp.205-230

Nakaharo, Y. (1990) Japanese Joinery: A Handbook for Joiners and Carpenters [Koichi Paul Nii, trans.], Hartley \& Marks, Vancouver

NEWBuildS (2015) Application of Analysis Tools from NEWBuildS Research Network in Design of a High-Rise Wood Building, NSERC Strategic Research Network on Innovative Wood Products and Building Systems (NEWBuildS) in partnership with FPInnovations

Pearson, A. (2016) 'Dalston Lane: Tall Timber', Building.co.uk, $20^{\text {th }}$ January 2016, http://www.building.co.uk/dalston-lane-tall-timber/5079749.article, accessed $29^{\text {th }}$ January 2016

Pei, S., van de Lindt, J., Popovski, M., Berman, J., Dolan, J., Ricles, J., Sause, R., Blomgren, H., and Rammer, D. (2016) 'Cross-Laminated Timber for Seismic Regions: Progress and Challenges for Research and Implementation', ASCE Journal of Structural Engineering, DOI: 10.1061/(ASCE)ST.1943-541X.0001192, E2514001. 
Foster, R.M., Reynolds, T.P.S. and Ramage M.H. (2016) "Proposal for defining a tall, timber building”, J. Struct. Eng., http://dx.doi.org/10.1061/(ASCE)ST.1943-541X.0001615

Perkins + Will (2014) Summary report: Survey of International Tall Wood Buildings with Appendices,

Perkins + Wills on behalf of Forestry Innovation International and Binational Softwood Lumber Council, May 2014

Reynolds, T., Harris, R. and Chang, W-S. (2014) 'Nonlinear pre-yield modal properties of timber structures with large-diameter steel dowel connections', Engineering Structures, Vol. 76, pp. 235-244, doi:10.1016/j.engstruct.2014.07.010

Reynolds, T., Casagrande, D. and Tomasi, R. (2016)' Comparison of multi-story cross-laminated timber and timber frame buildings by in-situ modal analysis', Construction and Building Materials, Vol. 102, No. 2, pp. 1009-1017, http://dx.doi.org/10.1016/j.conbuildmat.2015.09.056

Robinson, T., Hallova, A., Spiritos, J. and Roelefs, M. (2016) 'New heights for renewables: The US Tall Wood Building competition', CTBUH Journal, Issue 1, pp. 26-31

SOM (2013) Timber Tower Research Project: Final Report, Skidmore Owings and Merrill, Chicago, May $6^{\text {th }} 2013$

Thompson, H. (2009) 'A Process Revealed - Auf Dem Holzweg', Waugh, A., Weiss, K.H. and Wells, M. [Eds.], FUEL, London

Tomasi, R., and Smith, I. (2015) 'Experimental Characterization of Monotonic and Cyclic Loading Responses of CLT Panel-To-Foundation Angle Bracket Connections', ASCE Journal of Materials in Civil Engineering, Vol. 27, Issue 6, 10.1061/(ASCE)MT.1943-5533.0001144, 04014189

Willis, C. (1995) Form Follows Finance: Skyscrapers and Skylines in New York and Chicago, Princeton Architectural Press, New York

Yang, J. et al., (2004) 'Benchmark Problem for Response Control of Wind-Excited Tall Buildings', ASCE Journal of Engineering Mechanics, Vol. 130, No. 4, pp.437-446

Yeoh, D., Fragiacomo, M., De Francceschi, M. and Boon, K.H. (2011) 'State of the Art on TimberConcrete Composite Structures: Literature Review', ASCE Journal of Structural Engineering, Vol. 137, No. 10, pp. 1085-1095, [10.1061/(ASCE)ST.1943-541X.0000353]

Zarnani, P. and Quenneville, P. (2014) 'Splitting Strength of Small Dowel-Type Timber Connections: Rivet Joint Loaded Perpendicular to Grain' ASCE Journal of Structural Engineering, Vol. 140, No. 10, 10.1061/(ASCE)ST.1943-541X.0001039, 04014064.

Zhang, X., Fairhurst, M., and Tannert, T. (2015) 'Ductility Estimation for a Novel Timber-Steel Hybrid System', ASCE Journal of Structural Engineering, 10.1061/(ASCE)ST.1943541X.0001296, E4015001. 
Foster, R.M., Reynolds, T.P.S. and Ramage M.H. (2016) "Proposal for defining a tall, timber building", J. Struct. Eng., http://dx.doi.org/10.1061/(ASCE)ST.1943-541X.0001615

Table 1: Summary of structural systems adopted. The presence of concrete screeds is also noted where known.

\begin{tabular}{|c|c|c|c|c|}
\hline \multirow{2}{*}{ Building } & \multirow{2}{*}{ Stories } & \multicolumn{3}{|c|}{ Structural system } \\
\hline & & Vertical & Lateral & Flooring \\
\hline $\begin{array}{l}\text { E3, Berlin, } \\
\text { Germany }\end{array}$ & 7 & $\begin{array}{l}\text { column GL, wall } \\
\text { Brettstapel, core wall } \\
\text { RC }\end{array}$ & core $\mathbf{R C}$ & HBV (RC100) \\
\hline $\begin{array}{l}\text { Kingsgate House, } \\
\text { London, UK }\end{array}$ & 7 & wall CLT, RCGF & core + wall CLT & $\mathbf{C L T}+\mathbf{S C} ?$ \\
\hline $\begin{array}{l}\text { Strandparken, } \\
\text { Stockholm, Sweden }\end{array}$ & 7 & walls CLT, TF & $\begin{array}{l}\text { core + walls CLT-ST } \\
\text { (continuous tie) }\end{array}$ & $\begin{array}{l}\text { CLT-GL composite } \\
\text { (Martinson) }\end{array}$ \\
\hline $\begin{array}{l}\text { WIDC, Prince } \\
\text { George, BC }\end{array}$ & 7 & $\begin{array}{l}\text { column GL, LVL, } \\
\text { wall } \mathbf{C L T}, \mathbf{T F}\end{array}$ & core CLT & $\mathbf{G L}+\mathbf{C L T}$ \\
\hline $\begin{array}{l}\text { T3, Minneapolis, } \\
\text { MN }\end{array}$ & 7 & $\begin{array}{l}\text { column GL, core } \\
\text { RC, RCGF }\end{array}$ & core $\mathbf{R C}$ & $\begin{array}{l}\text { beam GL + NLT + } \\
\text { SC? }\end{array}$ \\
\hline UEA, Norwich, UK & 8 & CLT wall & core + wall CLT & CLT + Sc55 \\
\hline $\begin{array}{l}\text { Limnologen, Växjö, } \\
\text { Sweden }\end{array}$ & 8 & $\begin{array}{l}\text { wall CLT, TF, } \\
\text { column GL, RCGF }\end{array}$ & $\begin{array}{l}\text { core + wall CLT- ST } \\
\text { (continuous tie) }\end{array}$ & GL-CLT composite \\
\hline $\begin{array}{l}\text { LCT One, Donbirn, } \\
\text { Austria }\end{array}$ & 8 & $\begin{array}{l}\text { column GL, wall } \\
\text { RC, RCGF }\end{array}$ & core $\mathbf{R C}$ & HBV (RC80) \\
\hline $\begin{array}{l}\text { Holz8, Bad Aibling, } \\
\text { Germany }\end{array}$ & 8 & wall $\mathbf{T F}$ & $\begin{array}{l}\text { core } \mathbf{R C}+\text { wall } \mathbf{T F}- \\
\mathbf{S T} \text { (continuous tie) }\end{array}$ & CLT + Sc? \\
\hline $\begin{array}{l}\text { Butler Square, } \\
\text { Minneapolis, MN }\end{array}$ & 9 & $\begin{array}{l}\text { wall masonry, } \\
\text { column timber }\end{array}$ & wall masonry & beams timber \\
\hline $\begin{array}{l}\text { Cenni di } \\
\text { Cambiamento, } \\
\text { Milan, Italy }\end{array}$ & 9 & wall CLT & core + wall CLT & $\mathbf{C L T}+?$ \\
\hline $\begin{array}{l}\text { Murray Grove, } \\
\text { London, UK }\end{array}$ & 9 & wall CLT, RCGF & core + wall CLT & CLT + Sc55 \\
\hline $\begin{array}{l}\text { Dalston Lane, } \\
\text { London, UK }\end{array}$ & 10 & wall CLT, RCGF & core + wall CLT & CLT + Sc55 \\
\hline $\begin{array}{l}\text { Forté Building, } \\
\text { Melbourne, } \\
\text { Australia }\end{array}$ & 10 & wall CLT, RCGF & core + wall CLT & CLT + SC70 \\
\hline $\begin{array}{l}\text { Wenlocke Road, } \\
\text { London, UK }\end{array}$ & 10 & $\begin{array}{l}\text { column ST, wall } \\
\text { CLT, core wall } \mathbf{R C} \text {, } \\
\text { RCGF }\end{array}$ & core $\mathbf{R C}$ & CLT + ? \\
\hline $\begin{array}{l}457 \text { West } 18^{\text {th }}, \text { New } \\
\text { York, NY* } \\
\text { (Robinson et al. } \\
\text { 2016) }\end{array}$ & 10 & $\begin{array}{l}\text { core + wall CLT, } \\
\text { column GL }\end{array}$ & core + wall CLT & $\mathbf{C L T}+\mathbf{S C} ?$ \\
\hline
\end{tabular}


Foster, R.M., Reynolds, T.P.S. and Ramage M.H. (2016) "Proposal for defining a tall, timber building”, J. Struct. Eng., http://dx.doi.org/10.1061/(ASCE)ST.1943-541X.0001615

\begin{tabular}{|c|c|c|c|c|}
\hline $\begin{array}{l}\text { FFTT 12, } \\
\text { Vancouver, BC* } \\
\text { (Green and Karsh } \\
\text { 2012) }\end{array}$ & 12 & $\begin{array}{l}\text { column GL, wall } \\
\text { CLT }\end{array}$ & core CLT & CLT + Sc40 \\
\hline $\begin{array}{l}\text { Framework, } \\
\text { Portland, OR* } \\
\text { (Robinson et al. } \\
\text { 2016) }\end{array}$ & 12 & $\begin{array}{l}\text { core PT CLT, } \\
\text { column GL }\end{array}$ & core PT CLT & $\begin{array}{l}\text { beam } \mathbf{G L}+\mathbf{C L T}+ \\
\text { SC? }\end{array}$ \\
\hline $\begin{array}{l}\text { Treet, Bergen, } \\
\text { Norway }\end{array}$ & 14 & $\begin{array}{l}\text { column GL, modules } \\
\text { TF/CLT, RCGF }\end{array}$ & braced GL & $\begin{array}{l}\text { TF, (truss GL + } \\
\text { RC200) } / 5^{\text {th }} \text { story }\end{array}$ \\
\hline $\begin{array}{l}\text { UBC Brock } \\
\text { Building, } \\
\text { Vancouver, BC* }\end{array}$ & 18 & $\begin{array}{l}\text { GL + RC core, } \\
\text { RCGF }\end{array}$ & core $\mathbf{R C}$ & CLT \\
\hline $\begin{array}{l}\text { NEWBuildS, } \\
\text { Vancouver, BC* } \\
\text { (NEWBuildS 2015) }\end{array}$ & 20 & $\begin{array}{l}\text { column GL, wall } \\
\text { CLT, RCGF }\end{array}$ & $\begin{array}{l}\text { core-wall CLT- link } \\
\text { ST }\end{array}$ & HBV (125 mm RC) \\
\hline $\begin{array}{l}\text { FFTT 30, } \\
\text { Vancouver, BC* } \\
\text { (Green and Karsh } \\
\text { 2012) }\end{array}$ & 30 & wall CLT & $\begin{array}{l}\text { core-wall CLT or } \\
\text { core-frame CLT-ST }\end{array}$ & CLT + Sc40 \\
\hline $\begin{array}{l}\text { SOM 'CJTF', } \\
\text { Chicago, IL*'(SOM } \\
\text { 2013) }\end{array}$ & 42 & $\begin{array}{l}\text { column GL, wall } \\
\text { CLT, RC1F }\end{array}$ & $\begin{array}{l}\text { core-wall CLT- link } \\
\text { RC }\end{array}$ & CLT-spandrel RC \\
\hline $\begin{array}{l}\text { SOM 'All Timber', } \\
\text { Chicago, IL* (SOM } \\
2103)\end{array}$ & 42 & $\begin{array}{l}\text { column GL, wall } \\
\text { CLT, RC1F }\end{array}$ & $\begin{array}{l}\text { core-wall CLT-link } \\
\text { GL }\end{array}$ & CLT \\
\hline
\end{tabular}

* Unrealized building at the time of writing

Note on abbreviations - 'CLT' indicates cross-laminated timber, 'RC\#' indicates reinforced concrete of thickness \# mm, 'SC\#' indicates non-structural concrete screed of thickness \# mm, 'Sc?' indicates nonstructural screed of unknown thickness, 'TF' indicates timber framed panel construction, 'GL' indicates glue-laminated timber, 'HBV' is a proprietary RC-GL composite system, 'ST' indicates steel, 'RCGF' indicates ground floor podium level with concrete transfer slab above, ' $\mathbf{R C 1 F}$ ' indicates concrete ground and $1^{\text {st }}$ floor with concrete transfer slab above, 'NLT' indicates nail-laminated timber, 'PT' indicates posttensioning. 